\title{
Anatomical and nutlet differentiation between Teucrium montanum and T. polium from Turkey
}

\author{
Muhittin Dinç ${ }^{1}$, Süleyman DoĞU${ }^{2}$, Aslı DoĞRu KocA ${ }^{3} \&$ Baştürk KAYA $^{1}$ \\ ${ }^{1}$ Selçuk University, Faculty of Education, Department of Biology, 42090 Meram, Konya, Turkey; e-mail: \\ muhdinc@yahoo.com \\ ${ }^{2}$ Selçuk University, Faculty of Education, Department of Science Education, 42090 Meram, Konya, Turkey \\ ${ }^{3}$ Hacettepe University, Faculty of Science, Department of Biology, 06800 Beytepe, Ankara, Turkey
}

\begin{abstract}
Teucrium montanum L. and T. polium L. are the two closest Teucrium L. species from sect. Polium (Mill.) Schreb in Turkey. In addition, they are sympatric for some part of their range in Turkey. In this study, comparative anatomical and micromorphological studies of the two species are carried out. They have been investigated by their leaf and stem anatomical features, as well as nutlet micromorphological characteristics. The results of anatomical studies show that the anatomical characters of both taxa are observed to be similar to the general features of the family Lamiaceae anatomy, except for lacking rich collenchyma at the corners. Both taxa are similar in stem anatomy and their leaves exhibit xeromorphy. However, trichome morphology on the stems and the leaves appear to have a taxonomic value in segregation of the two taxa. Light and scanning electron microscope studies on the nutlets also show that nutlet shapes, measures and surface micromorphologies are different in the two species. Whereas nutlet surfaces are bireticulate in both species, the nutlets are larger and primary sculpturing is more distinct in T. polium than in T. montanum. Moreover, the nutlets are oblong to oblong-ovoid and larger in T. polium, but ovoid and smaller in T. montanum.
\end{abstract}

Key words: Teucrium; Polium; anatomy; micromorphology; taxonomy; Lamiaceae; Turkey

\section{Introduction}

Teucrium $\mathrm{L}$. is a polymorphic and wide spreading genus which is commonly grown in Europe, North Africa and in the temperate parts of Asia (Bentham 1835). Owing to classifying into sections based on the some variable morphological characters, there were some confusion about limitation of sections and interspecific relationships in the genus. The recent investigations on pollen, trichome and nutlet morphology, and vegetative anatomy have showed that these characters have taxonomical value on sectional and interspecific classification in the genus Teucrium (Oybak \& Inceoğlu 1988; Marín et al. 1994; Navarro \& El Qualidi 2000; Jurišić Grubešić et al. 2007; Dinç et al. 2008a,b; Dinç et al. 2009).

Teucrium genus comprises 32 species, 10 subspecies, 2 variety, totally 44 taxa belonging to 8 sections in Turkish flora (Ekim 1982; Duman 2000; Dönmez 2006; Yildirımli 2008). Section Polium is represented by two species in Turkey. These species are Teucrium montanum and T. polium. The external morphological differences between them are sometimes subtle and they are sympatric for some part of their range in Turkey. The objectives of this study are to provide a detailed description of nutlet morphology, and anatomical structure of the stem and leaf in Teucrium sect. Polium in Turkey by using light and scanning electron microscopy, and to evaluate the systematic significance of such characteristics in segregating the two species.

\section{Material and methods}

The studies were based on the plant materials collected by the authors and the herbarium specimens of T. polium and T. montanum kept at the herbarium KNYA. Collecting data for the two studied Teucrium species are given in Table 1 Some plant samples collected by the authors were fixed in $70 \%$ alcohol. Anatomical investigations were performed on the cross-sections of the upper stems and leaves, and the surface sections of leaves. The cross-sections were painted with basic fucsin and covered with glycerin-gelatin (Vardar 1987). Photographs of them were taken with Olympus BX-50 microscope. The stomatal index is calculated as described by Meidner \& Mansfield (1968). Similar features of T. polium and T. montanum are not emphasized during the presentation of the anatomical results.

Nutlets were previously observed using a stereomicroscope (Olympus BX-50) to ensure that they were of normal size and maturity. Measurements of the length and width were taken of 40 mature nutlets per specimen of each taxon under Olympus stereo-microscope. The obtained data explained as minimum-maximum and mean \pm standard deviation, and discussed using univariate (box-plots) clarified the SPSS 10.0 statistical package. In addition, five mature nutlets from each species were also mounted directly on aluminum stubs and covered with gold. After coating, they 
Table 1. The studied materials of T. polium and T. montanum.

\begin{tabular}{|c|c|c|}
\hline Species & Locality & Collection data \\
\hline \multirow[t]{3}{*}{ T. polium } & $\begin{array}{l}\text { C5 MERSIN: Aslanköy, Cocakdere, Katyyayla, mixed forest, clearings, } 1700- \\
1900 \text { m a.s.l., 06.07.2003 }\end{array}$ & $\begin{array}{l}\text { M. Dinç } 2031 \& \text { H.H. Doğan } \\
\text { (KNYA) }\end{array}$ \\
\hline & B5 AKSARAY: Ekicek Dağı, rocky places, 2100 m a.s.l., 06.07.1996 & M. Dinç $233^{b}$ (KNYA) \\
\hline & $\begin{array}{l}\text { C5 Nĭ̆GE: Ulukışla, Çiftehan, Horozköy, gardens, } 1200-1350 \mathrm{~m} \text { a.s.l., } \\
\text { 30.07.1984. }\end{array}$ & $\begin{array}{l}\text { S. Yildirimli } 7129^{b} \text { (Herb. Yil- } \\
\text { dirimli \& HUB) }\end{array}$ \\
\hline \multirow[t]{3}{*}{ T. montanum } & $\begin{array}{l}\text { C5 NIĞGDE: Ulukışla, between Ali Hoca village and Çiftehan, steppe, } 1100 \mathrm{~m} \\
\text { a.s.l., 09.08.2007 }\end{array}$ & $\begin{array}{l}\text { A. Duran 7704, Y. Bağcı \& M. } \\
\text { Dinç }^{b} \text { (KNYA) }\end{array}$ \\
\hline & $\begin{array}{l}\text { C5 KARAMAN: Ayrancl, above Çatköy, alpine steppe, } 1950 \mathrm{~m} \text { a.s.l., } \\
25.08 .2007\end{array}$ & $\begin{array}{l}\text { M. Dinç } 3065 \text { \& S. Doğu }{ }^{b, c} \\
\text { (Yildirimli Herb.) }\end{array}$ \\
\hline & $\begin{array}{l}\text { C4 KARAMAN: Sarıveliler, Yalman hill, Quercus clearings, } 1250 \mathrm{~m} \text { a.s.l., } \\
\text { 23.05.2007 }\end{array}$ & S. Doğu $905^{a}(\mathrm{KNYA})$ \\
\hline
\end{tabular}

${ }^{a}$ The specimens used for the anatomical studies

${ }^{b}$ The specimens used for the nutlet studies using stereo-microscope

${ }^{c}$ The specimens used for the nutlet studies using SEM
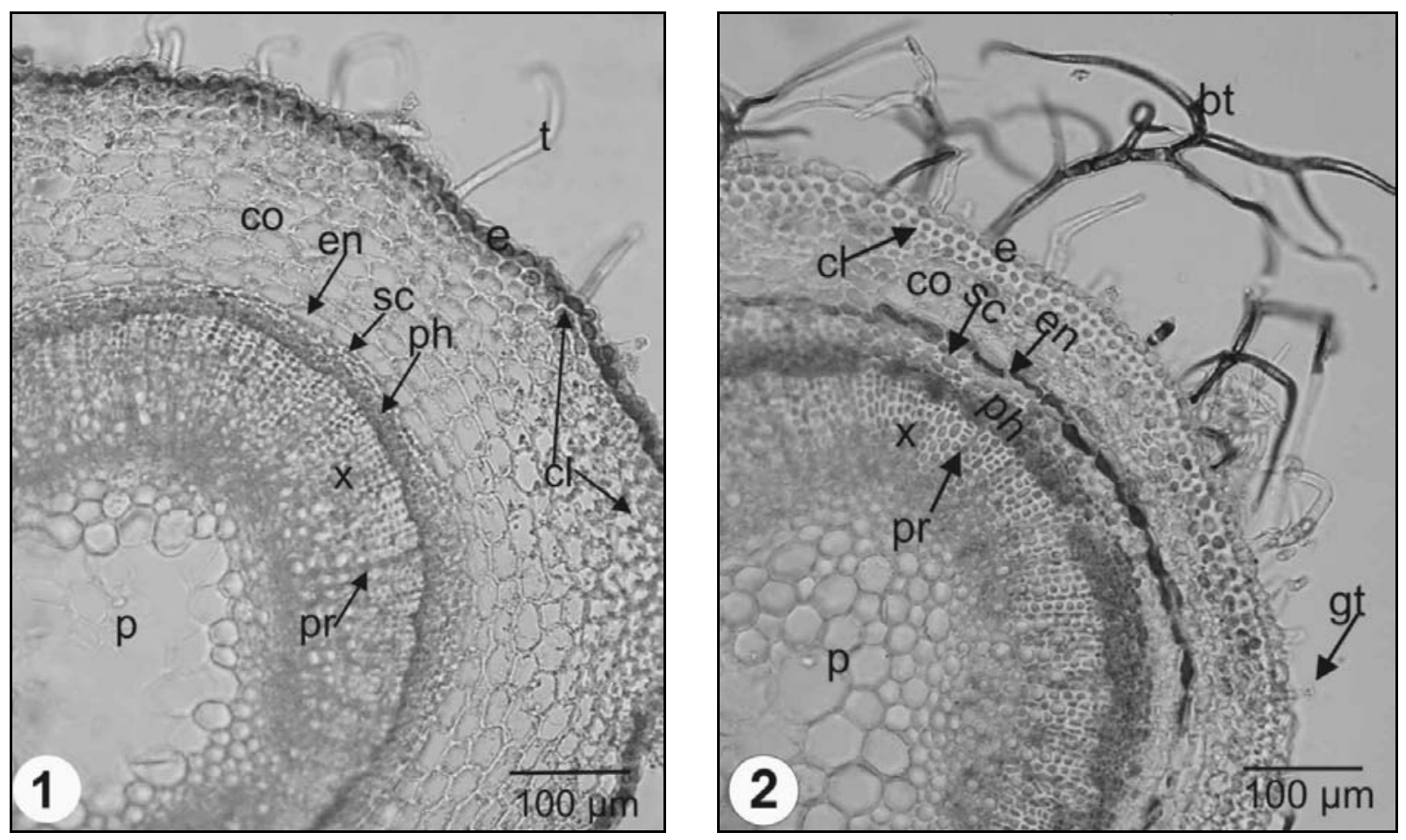

Figs 1-2. Transections of stems. $1-$ T. montanum; $2-$ T. polium; e, epidermis; t, broken flagelliform trichome (hair); bt, branched trichome; gt, glandular trichome; cl, collenchyma; co, cortex; en, endodermis; sc, sclerenchyma; pr, pith ray; ph, phloem; x, xylem; p, pith.

were observed and photographed by a scanning electron microscope.

\section{Results}

\section{Anatomical properties}

Stem: It is roughly terete in cross-section. The surface is covered by the epidermis. The epidermis consists of a single layer rectangular to ovoidal cells, and is surrounded by a cuticle layer. There are multicellular trichomes on the epidermis. In T. polium, the multicellular trichomes are branched (cladose), but in $T$. montanum, the multicellular trichomes are uniseriate, fairly long and whip-like (flagelliform). There are also few capitate-glandular trichomes on the epidermis. Underneath the epidermis, collenchyma is present. It is single layered between the corners and 6-7 layered in the corner of the stem. The shape of collenchyma cells is ovoid to orbicular. 4-5 layered parenchymatic cortex is located below collenchyma. Parenchymatic cortex cells are flattened and rectangular. Endodermis is distinguishable and composed of 1-2 layers of rectangular cells. The pericycle is present between the endodermis and the phloem elements and made up of 1-3 layered sclerenchymatous cells encircling the vascular tissue from the outside. There are sclerenchyma fibres have also been observed. Cambium is indistinguishable. The xylem is composed of trachea and tracheids. The 

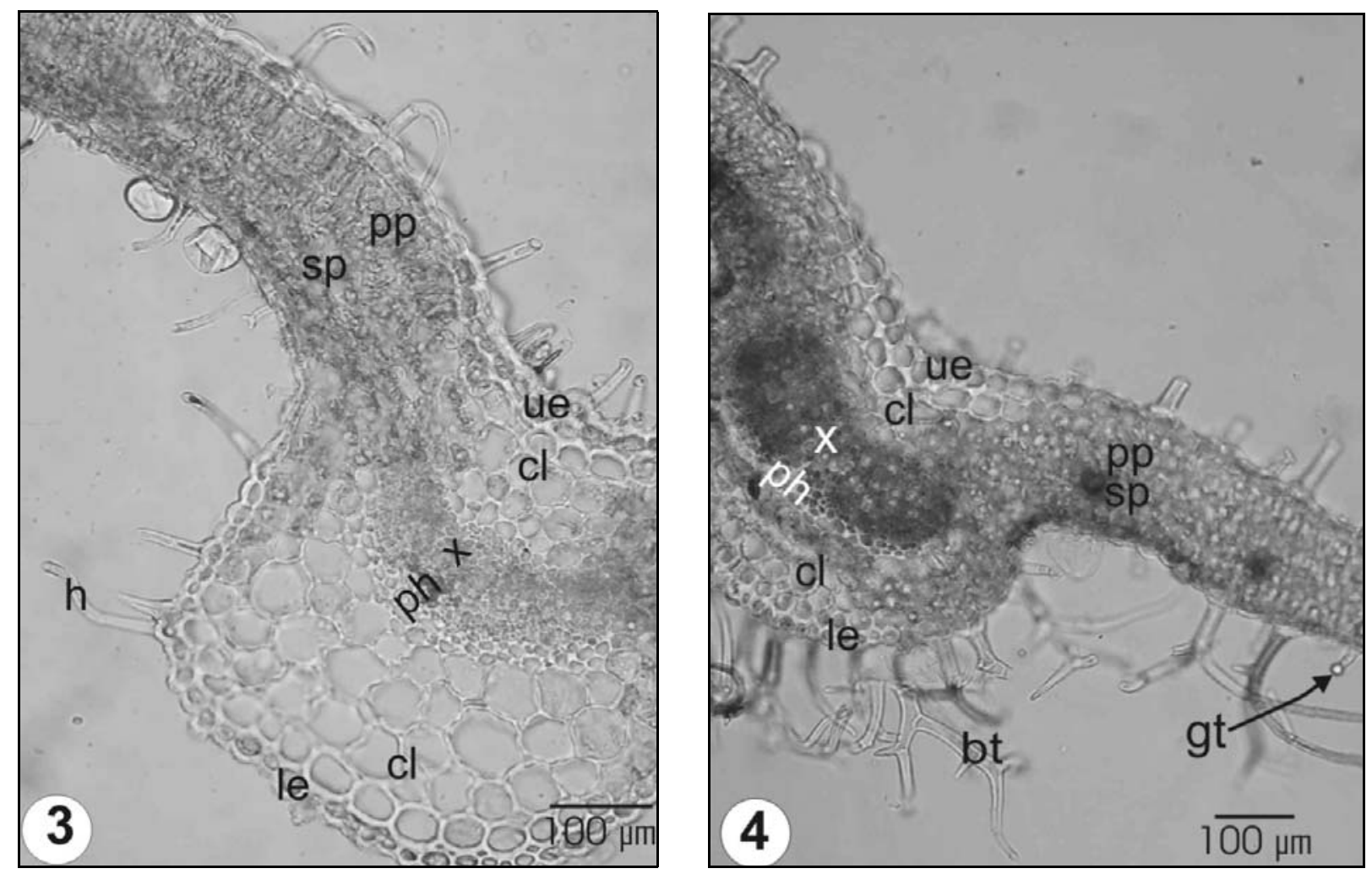

Figs 3-4. Transections of the leaves. 3 - T. montanum; 4- T. polium; ue, upper epidermis; cl, collenchyma; x, xylem; ph, phloem; pp, palisade parenchyma; sp, spongy parenchyma; le, lower epidermis; $h$, broken flagelliform trichome; bt, branched trichome; gt, glandular trichome.

pith rays are 1-2 layered. The pith is present in the middle of the stem. It is hollow in the centre and the parenchymatic cells are present in outer part (Figs 1, 2).

Leaf: Both surfaces are covered by the epidermis. The upper and the lower epidermises consist of a single layer rectangular to ovoidal cells, and is surrounded by a cuticle layer. The upper epidermis cells are larger than the lower ones. The upper epidermis cell walls are fairly thicker than the lower ones. Both epidermises are covered with a cuticle. The upper cuticle layer is about as thick as the lower one. There are branched trichomes on both epidermises of $T$. polium leaf, but flagelliform trichomes are present on those in T. montanum. The branched trichomes are 5-10-branched, and the flagelliform trichomes are multicellular, uniseriate, fairly long and whip-like. The walls of the lower epidermis cells are more corrugated than those of upper epidermis. Midrib is rich in collenchymatic elements. There are 4-5 layered collenchyma below the midrib, and 2-3 layered collenchyma above the midrib. The lower collenchymatic cells are larger than the upper ones. Leaves are bifacial and hypostomatic. The palisade and spongy parenchyma are distinct. The stomata are anomocytic and the guard cells row below the epidermis (xeromorphic type). Palisade parenchyma cells are 2-layered under the upper epidermis. Spongy parenchyma cells are 2-3 layered under the lower epidermis. However, the palisade parenchyma occupies about $55-60 \%$ of the mesophyll. (Figs 3, 4).

The leaf surface sections show that the leaves are hypostomatic (the upper surface of the leaf lacks stoma) with anomocytic type stomata and the wall of the upper epidermal cells is thicker than the one of the lower epidermal cells. The pit pairs can be seen on the upper epidermis cells walls.

In T. montanum, the number of stomata is $112 \pm 8$ per $\mathrm{mm}^{2}$, and the size of the epidermal cells is $358 \pm 10$ per $\mathrm{mm}^{2}$ on the lower leaf surface. The stomatal index is 23.8. The stoma cells form a row below the epidermis (xeromorphic type).

In T. polium, the number of stomata is $120 \pm 8$ per $\mathrm{mm}^{2}$, and the size of the epidermal cells is $376 \pm 10$ per $\mathrm{mm}^{2}$ on the lower leaf surface. The stomatal index is 24.2. The stoma cells form a row below the epidermis (xeromorphic type) (Figs 5-8).

Nutlet morphology: In T. montanum, the nutlets are ovoid, range from $1.00 \mathrm{~mm}$ to $2.00 \mathrm{~mm}$ in lenght, and from $0.50 \mathrm{~mm}$ to $1.20 \mathrm{~mm}$ in width (Table 2). The surface show bireticulate sculpturing. Suprareticulum meshs are indistinct, tending to smooth, infrareticulum meshs range from $10 \mu \mathrm{m}$ to $20 \mu \mathrm{m}$ (Figs 9, 10). In $T$. polium, the nutlets are oblong to oblong-ovoid, range from $1.80 \mathrm{~mm}$ to $2.90 \mathrm{~mm}$ in lenght, and from $1.00 \mathrm{~mm}$ to $2.00 \mathrm{~mm}$ in width (Table 2). The surface show bireticulate sculpturing. Suprareticulum meshes are distinct, vary from $150 \mu \mathrm{m}$ to $500 \mu \mathrm{m}$, and infrareticulum meshes are in range from $10 \mu \mathrm{m}$ to $20 \mu \mathrm{m}$ (Figs 11, 12). The box-plots (univariate statistics) analysis of the means obtained from nutlet length and nutlet width of different populations of Teucrium montanum and T. polium show significant differentiation between the two species 

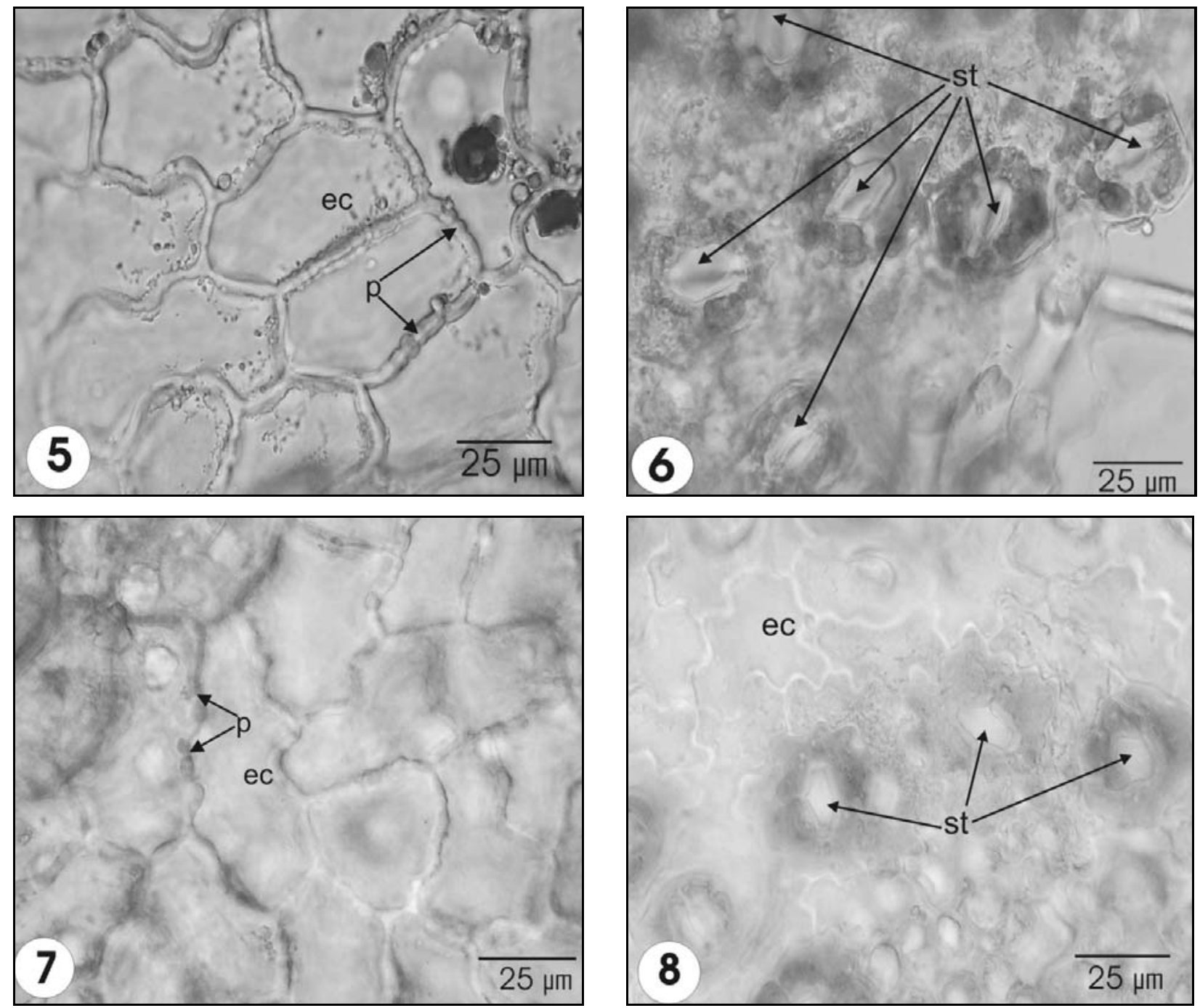

Figs 5-8. Surface sections of the leaves. 5 - Upper leaf surface of T. montanum; 6 - Lower leaf surface of T. montanum; 7 - Upper leaf surface of $T$. polium; 8 - Lower leaf surface of T. polium; st, stoma; ec, epidermal cell; p, pit.

Table 2. Nutlet measurements (mm) of T. polium (VAR1, VAR2, VAR3) and T. montanum (VAR4, VAR5, VAR6).

\begin{tabular}{|c|c|c|c|c|}
\hline & \multicolumn{2}{|r|}{ Nutlet length } & \multicolumn{2}{|r|}{ Nutlet width } \\
\hline & Min.-max & Mean \pm standard deviation & Min.-max & Mean \pm standard deviation \\
\hline \multicolumn{5}{|c|}{ T. polium } \\
\hline VAR1 & $1.90-2.90$ & $2.29 \pm 0.25$ & $1.00-1.90$ & $1.40 \pm 0.18$ \\
\hline VAR2 & $1.80-2.70$ & $2.20 \pm 0.25$ & $1.00-1.70$ & $1.41 \pm 0.12$ \\
\hline VAR3 & $2.00-2.80$ & $2.30 \pm 0.20$ & $1.20-2.00$ & $1.52 \pm 0.18$ \\
\hline \multicolumn{5}{|c|}{ T. montanum } \\
\hline VAR4 & $1.00-2.00$ & $1.42 \pm 0.23$ & $0.50-1.20$ & $0.82 \pm 0.15$ \\
\hline VAR5 & $1.00-1.80$ & $1.26 \pm 0.16$ & $0.60-1.10$ & $0.77 \pm 0.12$ \\
\hline VAR6 & $1.00-1.60$ & $1.25 \pm 0.13$ & $0.50-1.00$ & $0.73 \pm 0.13$ \\
\hline
\end{tabular}

(Fig. 13). As seen in Fig. 13, for the nutlet lenght and width, only low or extremely low values of $T$. polium coincide with only high or extremely high ones of $T$. montanum in some populations.

\section{Discussion}

Teucrium Sect. Polium is the most heterogeneus section as regards trichome type and distribution (Navarro \&
El Qualidi 2000). Jurišić Grubešić et al. (2007) found that the wild populations of T. montanum in Carotia did not have flagelliform trichomes on their leaves and the stems, and the wild populations of T. polium have branched trichomes on the stems and leaves. Our results agree with the Jurišić Grubešić et al. (2007) for T. polium, but, T. montanum from Turkey have flagelliform trichomes on its leaves and stems in contradistinction to Jurišić Grubešić et al. (2007). 

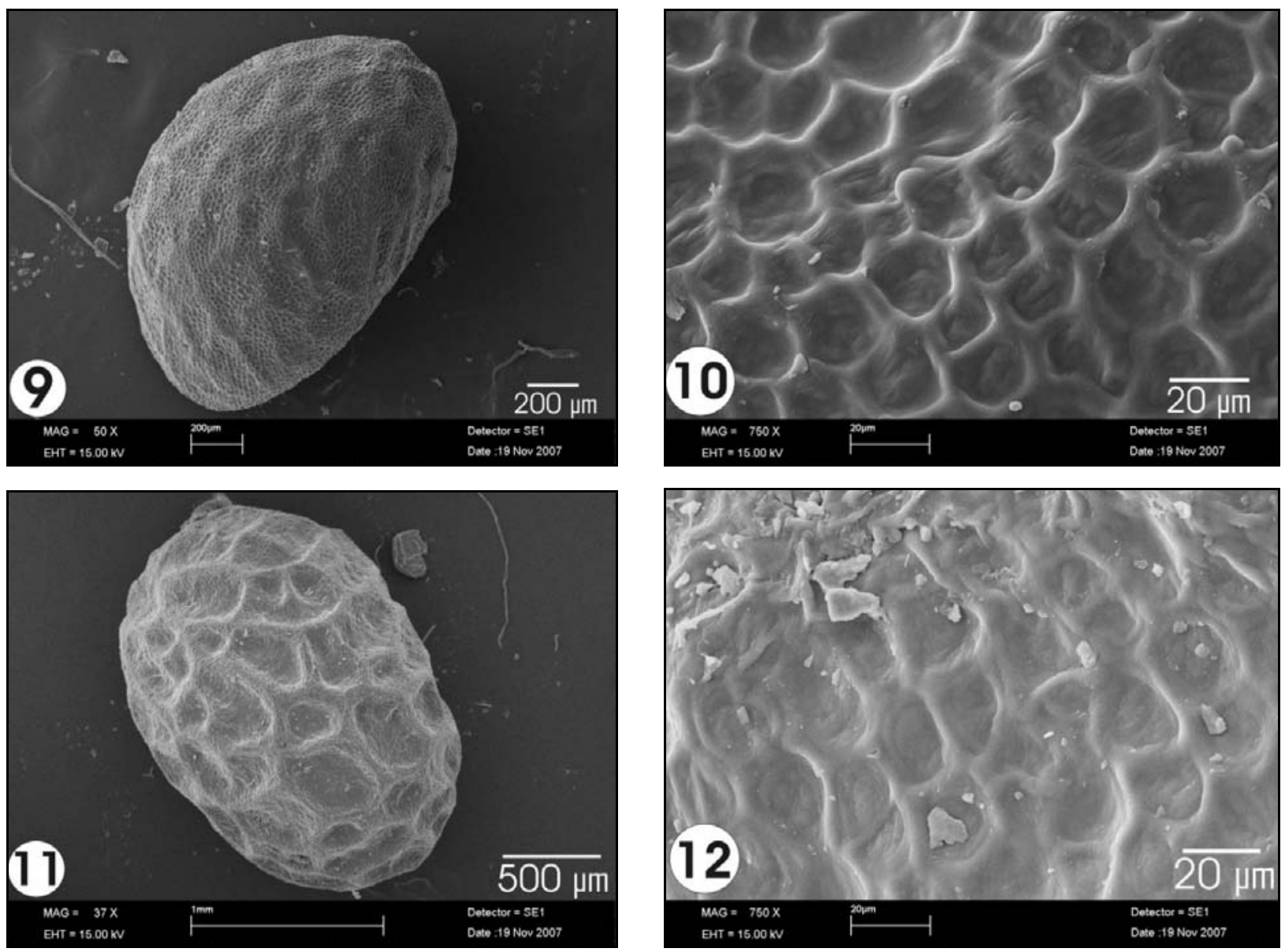

Figs 9-12. SEM micrographs of the nutlets of Teucrium montanum $(9,10)$ and T. polium $(11,12)$. Figs 9 and 11 represent general appearances of the nutlets, while Figs 10 and 12 show the nutlet surfaces in detail.
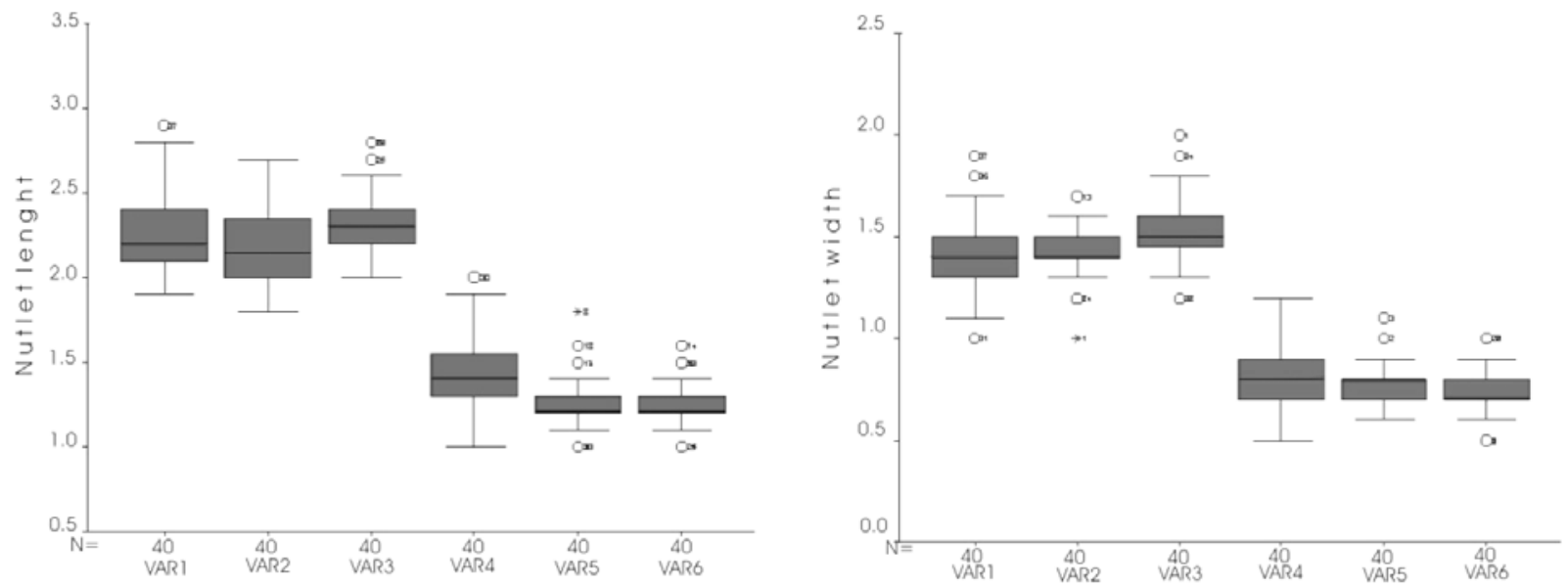

Fig. 13. Variation (box-plots) in nutlet length and width of different populations of Teucrium montanum (VAR 4, 5, 6) and T. polium (VAR 1, 2,3) from Turkey. Horizontal lines show median and circles represent extreme values.

The environment has a much greater influence on trichome dimension than on their formation or shape between the specimens of Teucrium species. Therefore, trichome shape has taxonomic significance in the genus Teucrium (Jurišić Grubešić et al. 2007). According to the results obtained in the present study, while the branched trichomes are mostly present in all vegetative parts of $T$. polium, the flagelliform hairs are present in those of T. montanum. The results related with the trichome morphology supported its taxonomic value.

Metcalfe \& Chalk (1950) pointed out that the stems of the family Lamiaceae species are rectangular and the collenchymatic tissue covers broad area at the corners, and a developed scleranchymatic tissue surrounds the vascular tissue. The anatomical studies on some of the genus Teucrium species showed that they had the same anatomical characteristics as well (Dinç et al. 2008a,b, 2009). In contradistinction to previously 
studied Teucrium species, the stems of sect. Polium species in Turkey are not conspicuously rectangular and the collenchymatic tissue does not cover broad area at the corners.

Solitary crystals and druses are the most common crystal types amongst dicotyledons, but other crystal types, such as spherocrystals are rarely observable. The more restricted occurrence of the spherocrystals enhances its diagnostic value (Metcalfe \& Chalk 1983). Spherocrystals are present in leaf epidermal cells of some species from section Teucrium and section Scordium (Dinç et al. 2008a,b, 2009). The presently studied species from section Polium lack spherocrystals.

Stomatal distribution on the leaves varies in Teucrium taxa. According to the studies previously carried out, the leaves are hypostomatic in Teucrium sandrasicum O. Schwarz and T. creticum L. from section Teucrium L. and T. scordium L. subsp. scordioides (Schreber) Maire \& Petitmengin from section Scordium Boiss., amphistomatic in T. chamaedrys L. subsp. tauricolum Rech. fil. from sect. Chamaedrys Benth. and $T$. orientale L. var. orientale from section Teucrium (Dinç et al. 2008a,b, 2009). The leaves are hypostomatic in the both species from section Polium (Mill.) Schreb. Although stomatal distribution on the leaves has taxonomic value in segregating some Teucrium species, it is not important in sectional classification of the genus Teucrium in the light of the present data.

Haired-nutlet represents a primitive character in the genus of Teucrium and has a phylogenetic value in the genus. Although it is seen in some species of Polium section (Marín et al. 1994), the studied species from the same section have the nutlets without hairs. Hovewer, the nutlet shape, size and surface micromorphology are useful in segregating Teucrium sect. Polium species in Turkey according to our results. While the nutlets of $T$. polium are oblong to oblong-ovoid, large and with distinct primary sculpturing, those of T. montanum are ovoid, smaller, and with less distinct primary sculpturing.

In conclusion, this study shows that trichome morphology, nutlet shape, measure and surface micromorphology have diagnostic value in segregation of the two closely related Teucrium species from sect. Polium. In addition, both taxa exhibit general characteristics of family Lamiaceae anatomy, but the stem is roughly terete with a poor collenchyma in contradistinction to previously studied Teucrium species.

\section{Acknowledgements}

We wish to express our hearty thanks to Prof. Dr. Şinasi Yildirimli, Prof. Dr. Ahmet Duran, Assoc. Prof. Dr. Hasan Hüseyin Doğan, and Assoc. Prof. Dr. Yavuz Bağcı for their helps for providing the materials.

\section{References}

Bentham G. 1835. Labiatarum genera et species. Teucrium, pp. 660-690. London.

Dinç M., Duran A., Pinar M. \& Öztürk M. 2008a. Anatomy, palynology and nutlet micromorphology of Turkish endemic Teucrium sandrasicum (Lamiaceae). Biologia 63: 637-641.

Dinç M., Doğu S., Bilgili B. \& Duran A. 2008b. T. chamaedrys L. subsp. tauricolum Rech.fil. ve T. scordium L. subsp. scordioides (Schreber) Maire \& Petitmengin (Labiatae) taksonları üzerine anatomik ve mikromorfolojik çalışmalar. Ot Sistematik Botanik Dergisi 14: 155-168.

Dinç M., Doğu S., Bilgili B. \& Duran A. 2009. Comparative anatomical and micromorphological studies on Teucrium creticum and Teucrium orientale var. orientale (T. sect. Teucrium, Lamiaceae). Nord. J. Bot. 27: 251-256.

Dönmez A. A. 2006. Teucrium chasmophyticum Rech. f. (Lamiaceae): A New Record for the Flora of Turkey. Turk. J. Bot. 30: $317-320$.

Duman H. 2000. Teucrium L., pp. 197-198. In: Güner, A., Özhatay N., Ekim T. \& Başer K.H.C. (eds), Flora of Turkey and the East Aegean Islands, vol. 11 (Supplement), Edinburgh Univ. Pres, Edinburgh.

Ekim T. 1982. Teucrium L., pp. 53-75. In: Davis P.H. (ed), Flora of Turkey and the East Aegean Islands, vol. 7, Edinburgh Univ. Press, Edinburgh, Royal Botanic Gardens, Kew.

Jurišić Grubešić R., Vladimir-Knežević S., Kremer D., Kaloera Z. \& Vuković J. 2007. Trichome micromorphology in Teucrium (Lamiaceae) species growing in Croatia. Biologia 62: 148156.

Marín D.P., Petkovic B. \& Duletic S. 1994. Nutlet sculpturing of selected Teucrium species (Lamiaceae): a character of taxonomic significance. Plant Syst. Evol. 192: 199-214.

Meidner H. \& Mansfield T.A. 1968. Physiology of Stomata. McGraw-Hill, London, pp. 138-141.

Metcalfe C.R. \& Chalk L. 1950. Anatomy of the Dicotyledons I., Oxford University Press., London, pp. 1041-1053.

Metcalfe C.R. \& Chalk L. 1983. Anatomy of the Dicotyledons II., Oxford University Press., London, pp. 82-91.

Navarro T. \& El Oualidi J. 2000. Trichome morphology in Teucrium L. (Labiatae). A taxonomic review. Anales Jard. Bot. Madrid, 57: 277-297.

Oybak-Dönmez E. \& Inceoğlu Ö. 1988. Pollen morphology of some Teucrium L. (Labiatae) species. Commun. Fac. Sci. Univ. Ank. Series C 6: 133-146.

Vardar Y. 1987. Botanikte Preparasyon Tekniği. Ege Üniversitesi Fen Fakültesi Baskı Işleri, Izmir, pp. 25-26.

Yildirimli Ş. 2008. The chorology of the Turkish species of Lamiaceae family. Ot Sistematik Botanik Dergisi 14: 151-198.

Received February 15, 2010 Accepted June 25, 2010 